\title{
'We Owned the Land Before the State Was Established': The State, Traditional Authorities, and Land Policy in Africa
}

\author{
Horman Chitonge
}

\begin{abstract}
This chapter looks at the land policy reform challenges in Africa, focusing on the struggle between the state and traditional leaders over the control of customary land. The governance of customary land is one of the most contentious land issues in Africa. As many African governments seek to reform land policies in order to respond to the challenges of population growth and urbanisation leading to the increasing demand for land, the proposed reforms are often challenged by traditional leaders who see the reforms as a ploy to undermine their authority over customary land. It is argued in this chapter that, while the state sometimes attempts to co-opt traditional leaders into cooperating with it, this alliance often does not hold for long, especially when traditional leaders sense that their interests are being undermined by proposed land policy reforms. Drawing from the Zambian experience, the chapter shows that although the state, as a sovereign entity, has the authority over all land under its territory, the situation is complicated by the fact that traditional leaders also assert authority over customary land. This situation sometimes leads to contestations that often frustrate the formulation and implementation of land policy reforms.
\end{abstract}

Keywords Customary land $\cdot$ Traditional authorities $\cdot$ State $\cdot$ Land policy reform • Contestation $\cdot$ Zambia

\section{Introduction}

This chapter looks at land policy reforms in Africa, focusing on the interplay between the state and traditional leaders regarding customary land administration and management. This is important because the largest part of land in Africa is still under customary tenure and land policy reforms are now highlighting the need to address

\footnotetext{
[Note on the chapter title] Chiefs and other traditional leaders argue that the people they govern owned the land before the colonial government established the state. Their claim to land is based on ancestral lineage, which precedes the establishment of the state.
}

H. Chitonge $(\bowtie)$

University of Cape Town, Cape Town, South Africa

e-mail: horman.chitonge@uct.ac.za 
customary land governance and administration arrangements. Land policy reforms have featured strongly in many African governments since the early 1990s, supported by two related policy agendas introduced during the 1980s as part of the broader strategy aimed at restructuring African economies to promote sustained growth. The first policy reform agenda focused on promoting the greater role of markets in the allocation of resources including land. With specific reference to land, there is a strong belief among international development agencies that customary land tenure, because of its alleged ambiguous (undefined) property rights, has failed to provide security of tenure, which is believed to be a precondition for markets in land to emerge (Feder and Nishio, 1999; Platteau, 2000; Deininger and Feder, 2009). In order to promoting the emergence of land markets to stimulate efficient use of the land, the World Bank and international donors advocated for privatising and titling of customary land (Deininger and Binswanger 1999).

The other policy reform agenda, closely related to the first, was the good governance programme, which was believed to be vital to the successful implementation of the structural adjustment programmes (SAPs) in Africa. Although the good governance agenda was only added later in the mid-1990s after a decade of implementing SAPs, it became a crucial component of policy reforms in Africa as donors realised that it would be difficult for markets to play a major role in society without capable and strong administrative institutions and capabilities. The experience of implementing SAPs during the 1980s made it clear that weak public institutional capacity and poor governance practices negatively impacted on the implementation and outcomes of the recommended reforms (see World Bank 2005).

In the case of land, it was observed that good land governance together with effective public institutions were central to securing land tenure rights and promoting the growth of land markets, investment, and productivity (IMF 1997; World Bank 1992; Deininger and Binswanger 1999; Deininger and Feder 2009). The good governance agenda was framed around promoting the principles of participation and transparency in the administration and governance of land as part of the drive to strengthen democratic governance principles (Amanor 2008). Most African governments embraced and started to implement these policy reforms, primarily to access the much-needed aid from international donors (Chimhowu 2019). A quick look at the land policy reforms in Africa reveals that majority of countries embarked on reforming national land policies and legislation during the 1990s following the advice of multilateral institutions and bilateral donors (Alden-Wily 2003). Donors and other multilateral institutions have remained the major drivers and sponsors of land policy reforms in most African countries even today (GIZ 2018), and their influence on land reforms remains significant.

The land policy reforms that started three decades ago have been on going, though in the later years, the framework and guidelines for reform have been provided and promoted by the African Union (AU/AfDB/ECA 2010). While the donors have been pushing for a pro-market land reform agenda since the 1990s, the implementation of the proposed reforms on the ground has faced many challenges including the contestation of the reforms by traditional leaders and other stakeholders. In pushing for these reforms, the donors and other international agencies assume that since the 
state is the sovereign entity entitled to formulate and implementing policy within its territory, if given the incentive (in the form of aid) it would implement the reforms. But the situation on the ground is quite complicated especially when it comes to the sensitive issue of customary land where the state encounters strong push back from those with vested interests. In mainstream theory of the state, the state is ascribed the sovereign right to formulate and implement policy within its boundaries, but when it comes to the issue of land in Africa, it seems that there are competing legitimacies as the case study presented in this chapter highlights.

The chapter looks at land policy reforms in Africa, focusing on the competing legitimacies between the state and traditional leaders over the governance and administration of customary land in particular. While sometimes the state seeks to create alliances with traditional leaders when it comes to the administration of customary land (Amanor 2008), there are cases when the state's interests and views are at variance with those of traditional leaders, leading to contestation. It is argued in this chapter that as the demand for land increases in many African countries due to several factors, including rising population, urbanisation, economic growth, and environmental dynamics, the contest for the control of customary land between the state and traditional authorities should be expected to intensify. This contest, as the case here shows, is not merely a matter of civil society challenging policy reforms; it, in a fundamental way, involves challenging the legitimacy of the state's claim over customary land. The key question is, on what basis do traditional authorities challenge the state's claim over customary land? To get some insight on this question, one has to delve deep into the politics of customary land in Africa.

The chapter presents a case study from Zambia where the process of approving the new land policy has been dominated by strong opposition from traditional leaders, who accuse the state of trying to sideline them. While the state, assisted by the African Union as well as other donor agencies including USAID, World Bank, UN Habitat (AU 2017), argues that the purpose of the reforms is to promote transparency and accountability in the way land is administered, traditional leaders on the other hand have argued that the proposed policy reforms not only undermine their role but endanger their existence. The tension that the proposed land policy reforms in Zambia has engendered became visible in early 2018 when traditional leaders stormed out of the stakeholder meeting meant to validate the Draft Land Policy. Such confrontations are not peculiar to Zambia; they have been reported in many African countries at various times when reforms to existing land policy are perceived to threaten traditional leaders' control over land (Berry 2017; Werner 2018). The state has often accused traditional leaders of being corrupt and lacking transparency in the way customary land is administered, citing the sale of land by some chiefs as evidence (Deininger and Feder 2009, 240; Ministry of Lands 2013).

The chapter is organised in six sections. The next section provides an overview of the politics of land in Africa, drawing from the current debates. This is followed by a brief overview of the land governance arrangements in Zambia. Section 3 provides a brief background to land resources in Zambia, including different categories of land, and how they are administered. Section 4 looks at the proposed land policy reforms in Zambia, presenting the argument of the state for supporting the reforms and the 
traditional leaders for rejecting sections of the proposed reforms. This is followed by a discussion of the apparent tension between the state and traditional authorities over the control and administration of customary land. The last section concludes the chapter.

\section{The Politics of Land in Africa}

Land in Africa, as in many parts of the world, is a critical resource. Consequently, control over land confers power and influence to those who exercise this function. This is one of the reasons why control over land administration has always been a contested terrain. Boni (2008) in his study of land dynamics in Akan region in Ghana shows that the contest over customary land is not just between the state and the traditional leaders; the authority over land of the latter is also challenged by local people. However, the two main contenders over customary land are traditional leaders and the state. Traditional leaders' authority over customary land is often derived from social, cultural, and historical ties to land, with some leaders tracing their claim to land to pre-colonial times, relying on what has been called the 'deeds of the ancestors' (Berry 2008). On the other hand, the modern African state's claim over land is rooted in the formal rules, including the constitution and international law, that accords territorial sovereignty to incumbent states. Thus, when traditional authorities are laying claim to or contesting new rules, policies, and structures over customary land administration, they appeal to the social practice and cultural norms through which land has been governed and shared in the past (Okoth-Ogendo 1989). Therefore, customary land in Africa is an arena where different types of claims converge, drawing from different sources to legitimise the claims.

While the state has the backing of formal law and politically validated processes, traditional leaders have the backing of cultural beliefs, traditional values, lineage narratives, and customary norms. In many rural communities in Africa, traditional leaders' control over land is believed to be stronger and more popular than the state's claim (Herbst 2000; Brown et al. 2016). This is evident in the fact that many rural residents still believe that customary land belongs to the ethnic groups, and that the chiefs and the village heads are the custodians of the land, wielding the power not only to allocate, but also to interpret and adjust traditional practices and norms around land (Blocher 2006). Boni (2008) has, however, contested this view, arguing that the different claims over customary land are validated not by tradition but by what he calls the 'interest driven politics', such that the state can lay claim to customary land when such a move furthers its interest. Traditional leaders do the same.

In the past, the state did not intrude much into the governance of customary land, with most states granting a large margin of discretion to traditional authorities to govern and administer customary land (Bruce 1982; Shipton and Goheen 1992; Lund 1998). But in recent years, as the demand for land grows, we are seeing an increasing trend among many African states seeking to reform customary land practices and governance structures to allegedly ensure transparency, accountability, and good 
governance in the management and administration of customary land. On the other hand, traditional leaders perceive these reforms as a threat not only to their power base, but their existence, given that the institution of traditional leaders derive its power and authority from the control over land (Lund 2006; Kabilika 2010). Land being a key resource, it is therefore not surprising that land policy reforms draw public attention in many countries, often leading to contestations (Lund 2006; Moyo 2008). As Nuesiri $(2014,7)$ observes, the

Struggles for control over and access to nature and natural resources; struggles over land, forests, pastures and fisheries are struggles for survival, self-determination, and meaning. Natural resources are central to rural lives and livelihoods; they provide the material resources for survival, security and freedom.

While the governance and administration of state land are largely clarified and less contested, the administration of customary land is increasingly contested, especially when the state attempts to usurp the authority and control of traditional leaders.

\subsection{Chiefs, the State, and Customary Land in Africa}

Issues around administration of customary land have been widely discussed in the literature on land and the state in Africa. The large body of literature on this topic supports the view that traditional authorities in their different forms tend to exercise control and authority over customary land even in cases where the state has attempted to usurp their powers (Van Binsbergen 1987; Shipton and Goheen 1992; Herbst 2000; Peters 2004; Boni 2008; Nuesiri 2014; Lund and Boone 2015; Chitonge 2015). However, there have been some analysts who have argued that, in some cases, the state has tactically chosen to forge alliances with traditional authorities in order to exercise control over the rural population (Amanor 2008). In cases where the state forges alliances with traditional leaders, it has been argued that post-colonial African states use traditional leaders in the same way as the colonial governments did through the principle of indirect rule (Bassett 1993; Mamdani 1996; Ntsebeza 2006). Baldwin (2011), in contrast to Herbst's (2000) argument that traditional leaders have amassed power because the state has no capacity to govern Africa's hinterland, argues that politicians deliberately choose to empower traditional authorities based on their political calculations. Boone (2017) has however shown that the state's relation with traditional authorities has been complicated partly by the introduction of multiparty politics and democratisation, which has created spaces where traditional authorities have become major political players due to their influence on the rural population.

While it is clear in this debate that traditional authorities have in recent years reasserted themselves (Amanor 2008; Nuesiri 2014) and are exercising increasingly growing influence in rural Africa, there has been little discussion in terms of what the source of this influence and power is. The dominant literature on the topic explains the power of traditional leaders over land in terms of the weak administrative capacity of the African states, characterised by the inability to project authority and control 
to far-flung areas (Herbst 2000). But this explanation would be true if there were no local government structures in rural areas. As things stand, local government structures exist in most rural areas in Africa, parallel with traditional authorities, and the central state can (and does) exercise control through these local structures. Yet, traditional leaders have not only remained popular; they are influential and trusted (Brown et al. 2016; Werner 2018).

When it comes to customary land, traditional authorities have often appealed to what I call 'soft power', which allows them to deploy history and culture as a power resource. For instance, traditional authorities in Zambia have argued that the proposed policy is seeking to undermine their role in land administration when in fact their ancestors owned the land even before the state was established. The legitimacy of traditional leaders is asserted not because of the vacuum left by a weak state, but by appealing to 'the deeds of the ancestors' as it were. As stakes in customary land rises, traditional authorities have resorted to what Boni (2006) has referred to as the 'ancestralisation of property' as the basis for asserting their legitimacy and control over land. In other words, they are using historical precedent and cultural history as the ground for asserting their authority over land (Berry 2008). I argue in this chapter that while the state bases its authority on the principle of sovereignty, which is a constitutionally guaranteed right, traditional authorities use a different route to assert their claim over land, and this leads to a clash because the two contending parties are using different power bases to assert the legitimacy of their claims.

\subsection{Riding on the Democratic Wave}

However, the power base for traditional authorities has been enhanced, since the third wave of democratisation in the early 1990s, characterised by the introduction of democratic principles, especially multiparty (competitive) politics, which forces politicians to consider the impact of their actions on electoral votes when engaging with traditional leaders. I would argue that by taking a conciliatory approach to engaging with traditional leaders, politicians are not just seeking to be 'nice' to nor colluding with traditional leaders; they do this to advance their own interests. Similarly, the state-traditional leader engagement is not just a matter of the state ceding power to traditional leaders to administer customary land in order to secure the rural vote (Baldwin 2011). African states have sometimes challenged the ancestral rights in land claimed by traditional leaders, using modern law and policy to delegitimise traditional authorities, in order to assert state control (Lund 2006). It would therefore seem that the relationship between the state and traditional leaders when it comes to land rests on a delicately constructed equilibrium. Changes to this finely tuned balance of power in Africa should therefore be expected to be conflict prone, as different actors seek to defend and sometimes expand their control over land (Boni 2008; Lund and Boones 2015).

The state formulates policies in various areas such as education, health, trade, investment, industrial, environment, and housing. Although all these policies may be 
contested, the level of contestation is heightened when it comes to land (Berry 2017). This is why the process of land policy formulation and approval takes a long time; some countries that started the process three decades ago are yet to finalise the policy (Alden Wily 2011). Land policy reform in Zambia discussed below is one example of a protracted process that has spanned over three decades, and the final policy has not been approved yet. In the case of land policy, this is not unusual given that the reforms ultimately lead to the reconfiguration of power and, as such, it is expected to be contested. To locate the contest over customary land in its broader context, there is need to analyse the complex state-traditional authorities' relations. What makes this relationship complex is that it is not fixed (cooperation or conflictual); at times, the state adopts a partnership approach (Amanor and Ubink 2008), while at other times, the state adopts a 'gentle subversive' posture, seeking to usurp the powers of traditional leaders in more subtle ways (Lund 2006). The broader context to all this is land governance.

\section{Land Governance in Africa}

Land governance can be understood in simple terms as the rules and policies that regulate the exercise of power and control over land. What is entailed in land governance is not so much the day-to-day activities of allocating and controlling the usage of land; it is about the rules that regulate the practices and institutional arrangements around land allocation, access, transfer, rental, and use. In this sense, land governance involves general rules and arrangements (institutions), formal or informal, through which the control or authority over land is mediated. Essentially, land governance is about how power relations around land are configured between the different land actors, at different levels. It is important to emphasise here that the structures and rules that guide and regulate the activities of land administrators are not cast in stones; they are negotiated and contested by the different actors who often stake their claims to reconfigure the power relations around land. Lund $(1998,2)$ has rightly described the dynamics around land governance in Africa when he observes that the structures and rules through which land is governed are 'not enduring absolutes, but rather outcomes of negotiations, contestation, compromise and deal making' - characterised by the condition he refers to as 'open moment'. This (open moment) occurs 'when the social rules and structures are suddenly challenged and the prerogatives and legitimacy of politico-legal institutions cease to be taken for granted' (ibid.). For example, in the case of Zambia, the prerogative of traditional leaders over customary land is challenged by the state's decision to create statutory bodies to administer customary land. On the other hand, traditional authorities' rejection of this policy indicates that the state's power over customary land should not be assumed to be a given. ${ }^{1}$

\footnotetext{
${ }^{1}$ It is important to make a distinction between land governance and land administration, noting that the latter is a part of the former. Land governance, as noted earlier, provides the framework
} 
Many African countries have outlined policies and legal frameworks to provide guidance around the exercise of power over land and the institutions involved in the day-to-day administration of land resources (Bruce 2014). In addition to the general legal and policy framework, there are also specific rules and guidelines that regulate the exercise of power over specific types of land. For example, there are different rules and pieces of legislation regarding the use of land under game reserves or nature conservation parks. These rules (both formal and informal) provide guidance on who has the power to make certain decisions and carry out administrative functions. As such, land governance everywhere is not just about land, it is fundamentally about the exercise of power over land-the politics of land (Lund and Boone 2015). Since the governance of land is about the exercise of power over land, it constitutes the core of land politics.

\subsection{Land and Statehood}

The fact that traditional leaders contest for the control of customary land has sometimes been interpreted as evidence of the weakness of states in Africa (Jackson and Rosberg 1982; Jackson 1990). For instance, it has been argued that traditional leaders are able to assert their authority over customary land primarily because African states are unable to project their authority over the entire territory, especially the far-flung rural areas, thereby creating a vacuum that is filed by traditional leaders (Herbst 2000). It has thus been argued (ibid. 172) that traditional leaders,

are often competitors to the centralised African state and are viewed as such by national leaders. The loyalties that citizens have towards these leaders, often expressed in a complex network of ethnic relations, is a significant challenge to African countries still having great difficulty ... in creating a national ethos.

Some analysts interpret the dominance of traditional leaders in rural areas as an indication of the inability of African states to exercise a monopoly of power over their territories, the failure to centralise power and hegemony (Jackson and Rosberg 1982).

For those who support this view, the existence of traditional leaders is understood as a competing power base in the conventional theory of the state and nation-building. This is clearly articulated in Tilly's (1985) notion of state formation as a process of conquering and subjugating competing entities in a specified territory. Drawing mainly from the European experience, the idea that the state should have no rivals in its territory is captured in the aphorism, 'war makes states' (Tilly 1985, 170), emphasising the view that states are made by conquering and subduing all the competing

through which land is administered. Land administration on the other hand relates to the dayto-day management of issues related to allocation, validation of ownership, application of the rules, resolution of disputes, keeping of records or any form of evidence, etc. In other words, land governance is a broader concept, which provides the rules and structures to regulate institutions and the decision-making mechanisms concerning the administration of land. 
entities in a territory to establish a 'monopoly of power'. In this understanding of statehood, the presence of anything that appears to rival the state is assumed to be a clear sign that the formation of the state is incomplete. In the case of Africa, the traditional leaders' claim over customary land, for instance, can then be perceived as a form of competition with the state. According to this view, a properly formed state should have no competing claims; it should have the monopoly of power within its territory. But this is a simplistic understanding of the state, particularly in Africa today.

The process of state formation today is much more complex than merely subjugating weaker or competing entities in the territory through the monopoly of violence. In modern democracies, violence is not a legitimating apparatus; legitimacy is built through various ways, including the electoral process, dialogue, and persuasion. The use of violence to silence opposition is seen as a sign of weakness and a huge democratic deficit. In fact, many African states tried using the 'monopoly of violence' strategy as a tool for creating political legitimacy through one-party states and in some cases military rule, prior to the introduction of competitive politics during the early 1990s (Young 2004). The repressive nature of most African governments during the 1980s came close to the ideal of not tolerating competing power bases, but these states had little legitimacy, and their statehood was widely questioned (Stark 1986).

The control over customary land that most traditional leaders in Africa assert is unlikely to be resolved by a show of force by the state, primarily because traditional leaders are not basing their claim on 'hard power'; they are contesting based on their ability to muster 'soft power' - the appeal to cultural beliefs, traditions, ethnic solidarity, and historical precedent as noted above. This is not an issue that can be resolved through the state asserting its monopoly of violence. In reality, while African states can indeed use 'hard power' to silence traditional leaders, most of them have not adopted this strategy; they have sought to engage the contesting parties, adopting a conciliatory stance, as the case presented below shows.

\section{Land in Zambia}

\subsection{Categories of Land}

Zambia has a total land mass of $752,614^{2} \mathrm{~km}^{2}$. Official figures from the Ministry of Lands suggest that of this, $94 \%$ is under customary tenure, with state land accounting for only $6 \%$ (GRZ 2006). ${ }^{3}$ While official figures show that the bulk of the land in Zambia is customary land, the size of land effectively controlled by traditional authorities is much smaller (Chitonge 2015; Honig and Mulenga 2015; Sitko et al.

\footnotetext{
${ }^{2}$ Different sources provide different figures on the size of the total land area for the county. Here, I will use the figure used in the Draft Land Policy (GRZ 2017, 2).

${ }^{3}$ The 2017 Draft Land Policy has revised the proportion of state land to less than 10\% (GRZ 2017, $3)$.
} 
Table 1 Categories of land in Zambia (2015)

\begin{tabular}{l|l|l|l|l}
\hline & Customary & Public & State & Total land mass \\
\hline Size (million, ha) & 31.2 & 36.7 & 7.5 & 75.3 \\
\hline Percent (\%) & 41.4 & 48.7 & 9.9 & 100 \\
\hline
\end{tabular}

Source Author, based on data from Draft Land Policy (GRZ 2017). Note: the category under customary land excludes all other pieces of land in customary areas managed by statutory bodies (see Table 2 for details)

2015; Mulolwa 2016). However, it is clear that although the land controlled by traditional leaders has been shrinking over time, customary land still accounts for the large portion (over 40\%) of land in Zambia, as Table 1 shows.

Table 1 provides an overview of the three broad land categories in hectares, while Table 2 provides the details of what constitutes state land and public land, including forest land, as of 2015. Although land in Zambia is broadly classified into two types of tenure (state and customary land), there are effectively three categories of land that are administered by different entities (Table 1).

The first category is state land. This is land largely under leasehold tenure. This category of land is administered and controlled by the Commissioner of Lands through the issuance of four types of leases to private individuals, companies, and trusts. The four leases are (1) Ten-year land record card, (2) a 14-year lease for unsurveyed land, (3) a 30-year occupancy licence (usually issued in housing improvement areas in peri-urban settlement), and (4) a 99-year renewable lease. Although the official documents show that state land is roughly around $10 \%$, there are other estimates suggesting that state land accounts for about $16.5 \%$ of the total land mass (Honig and Mulenga, 2015).

The second broad category of land is public land. This category of land consists of various pieces of land reserved for specific use including nature conservation, forests reserves, game reserves, wetlands, mountain range, and head waters (GRZ 2017, 22). Land falling under this category is administered by statutory bodies such as the Zambia Wildlife Authorities (ZAWA). This category of land accounts for close to half of the total land mass ( $8 \%$ under national parks, $22 \%$ under game management areas, 9\% under forest reserve areas, and 2\% wetlands (GRZ 2017, 16). While the larger portion of what is categorised as public land fall in customary areas, they are effectively not under the control of customary leaders. Land under the category national forest and national parks, particularly, are tightly regulated by statutory state bodies.

The third category of land is customary land. This is the category of land controlled by traditional authorities. If we consider the statement in the New Draft Land Policy that public land includes all pieces of land in customary areas that are "not allocated exclusively to any group, individual or family' (GRZ 2017, 22), it becomes obvious that traditional leaders control less than half of the land (see Table 2). If we take out local and national forests on customary land, the size of land controlled by customary authorities is about $40 \%$. It is important to note that figures under state land in Tables 1 
Table 2 Land resources in Zambia (2015)

\begin{tabular}{|c|c|c|c|c|c|c|}
\hline \multicolumn{3}{|c|}{ Public land } & \multicolumn{4}{|l|}{ State land } \\
\hline & Hectares & $\begin{array}{l}\text { Public as \% } \\
\text { of total land } \\
\text { mass }\end{array}$ & & Hectares & $\begin{array}{l}\text { State land as } \\
\% \text { of total } \\
\text { land mass }\end{array}$ & $\begin{array}{l}\% \text { of } \\
\text { state } \\
\text { land }\end{array}$ \\
\hline $\begin{array}{l}\text { National } \\
\text { Parks }\end{array}$ & $6,024,028$ & 8 & Crown land & $3,647,748$ & 4.8 & 55.0 \\
\hline GMA & $16,566,077$ & 22 & Farm Blocks & 531,500 & 0.7 & 8.0 \\
\hline Forest & $6,777,031$ & 9 & Urban Land & $1,400,000$ & 1.9 & 21.1 \\
\hline Wetland & $7,304,134$ & 9.7 & $\begin{array}{l}\text { Settlement } \\
\text { Schemes }\end{array}$ & 300,000 & 0.4 & 4.5 \\
\hline \multirow{4}{*}{$\begin{array}{l}\text { Total } \\
\text { public } \\
\text { land }\end{array}$} & $36,671,269$ & 48.7 & $\begin{array}{l}\text { Resettlement } \\
\text { Schemes }\end{array}$ & 750,000 & 0.99 & 11.3 \\
\hline & & & State land & $6,629,248$ & 8.8 & 100 \\
\hline & & & $\begin{array}{l}\text { Forest on State } \\
\text { land }\end{array}$ & 876,995 & 1.2 & 11.7 \\
\hline & & & $\begin{array}{l}\text { Total state } \\
\text { land }\end{array}$ & $7,506,243$ & 9.9 & 100 \\
\hline \multicolumn{3}{|c|}{ Forest land } & \multicolumn{4}{|l|}{ Customary land } \\
\hline & & Hectares & & & Hectares & $\begin{array}{l}\% \text { of } \\
\text { total }\end{array}$ \\
\hline \multicolumn{2}{|c|}{ Local forest in GMA } & 505,476 & \multicolumn{2}{|c|}{$\begin{array}{l}\text { Local forest on Customary } \\
\text { land }\end{array}$} & $1,363,403$ & 1.7 \\
\hline \multicolumn{2}{|c|}{$\begin{array}{l}\text { Local forest on } \\
\text { customary land }\end{array}$} & $1,363,403$ & \multicolumn{2}{|c|}{$\begin{array}{l}\text { National forest on } \\
\text { customary land }\end{array}$} & $3,161,303$ & 4.2 \\
\hline \multicolumn{2}{|c|}{ Local forest on state land } & 359,218 & \multicolumn{2}{|l|}{ Total } & $4,524,706$ & 6.0 \\
\hline \multicolumn{2}{|c|}{ National forest on GMA } & $2,087,524$ & \multicolumn{2}{|c|}{ Remaining customary land } & $31,201,294$ & 41.4 \\
\hline \multicolumn{2}{|c|}{$\begin{array}{l}\text { National forest on } \\
\text { customary land }\end{array}$} & $3,161,303$ & & & & \\
\hline \multicolumn{2}{|c|}{$\begin{array}{l}\text { National forest on state } \\
\text { land }\end{array}$} & 517,777 & & & & \\
\hline \multicolumn{2}{|c|}{ Total forest land } & 7,994,701 & & & & \\
\hline
\end{tabular}

Source Author, based on (Honig and Mulenga 2015; Mulolwa 2016; GRZ 2017)

Note GMA = Game Management Areas. Forest land under public land includes all types of forest including those on customary and state lands

Table 2, provides a breakdown of the three categories of land presented in Table1. From Table 2, it is clear that Public Land is made of four major subdivisions: National Parks, Game Management Areas (GMAs), forests, and wetlands. What is referred to as State Land is what during colonial rule was called Crown Land, plus the land acquired by the state for settlement, resettlement, farm blocks, and land in urban areas (towns and cities). Table 2 also breaks down Forest Land into different categories, including Forest Land in Customary as well as on State Land 
and 2 do not include land that has been converted from customary to leasehold tenure by private individuals since the land conversion policy came into effect in 1995. Even if we take a conservative estimate that $8.6 \%$ of total land had been converted from customary land by 2012 (Sitko et al. 2015, 17), it is apparent that land effectively under the control of traditional leaders is much less than the 94\% (GZR 2006) or 90\% (GRZ 2006, 2017) cited in official documents.

\subsection{Land Governance in Zambia}

Zambia, like many other African countries, since the introduction of colonial rule, has had a dual land tenure system: customary and statutory land tenure (state land). In precolonial times, land was governed through the customary tenure system which varied according to the local cultural norms and practices. Although the practices around land varied from community to community, one of the common elements of the customary tenure system is that land was controlled and administered by traditional leaders. In the traditional system, while traditional leaders played a central role in land administration, they were not regarded as owners of the land-land belonged to the community as a collective (Bruce 1982; Mamdani 1996). Their primary responsibility was to ensure access to land for all members of the community (Mafeje 2003).

Although there have been significant changes to the rules and structures governing land in Zambia after independence, the dual system has continued, with what used to be 'crown land' now renamed state land, while what used to be reserve and trust lands ${ }^{4}$ collectively renamed customary land. Thus, traditional leaders have been administering customary land for a long time. Most African states have always recognised and accepted this fact, including the role of traditional leaders when it comes to customary land (Alden Wily, 2011). In Zambia, the two important pieces of legislation regarding land (the Constitution and the 1995 Lands Act) have both recognised customary tenure and the institution of traditional leaders. For example, section 165 of the Constitution asserts: 'The institution of chieftaincy and traditional institutions are guaranteed and shall exist in accordance with the culture, customs and traditions of the people to whom they apply.' Similarly, section 254 clearly recognises the existence of customary land, stating: 'Land shall be delimited and classified as State land, customary land and such other classification, as prescribed.'

With specific reference to land administration, the Lands Act No 29 of 1995 (1995 Lands Act) also recognises both customary land and the administrative role of traditional leaders. Section 7(1) of the 1995 Lands Act stipulates that,

\footnotetext{
${ }^{4}$ Reserve land was specifically meant for use of indigenous people. Trust land was a category of 'unclassified land' called silent land and was meant to be allocated to the anticipated large inflows of European migrants after the Second World War. When the anticipated influx of Europeans did not occur, silent land was released for use by indigenous people. Reserve and trust lands together constitute what is referred to as a customary land.
} 
every piece of land in a customary area which immediately before the commencement of this Act was vested in or held by any person under customary tenure shall continue to be so held and recognised and any provision of this Act or any other law shall not be so construed as to infringe any customary right enjoyed by that person before the commencement of this Act.

Section 8(2) and (3) clearly allocates a central role to traditional leaders (chiefs) in the administration of customary land. These two sections make it clear that traditional leaders have a strong say in what happens to customary land (see Chap. 4). The recognition and role of traditional leaders when it comes to customary land is further reinforced in section 4, which states that: 'the President shall not alienate any land situated in a district or an area where land is held under customary tenure... without consulting the Chief ... in the area in which the land to be alienated is situated.' On the surface, this might appear as though the state is strengthening the role of traditional authorities in land administration. But when one reads this together with the policy allowing the conversion of customary land into leasehold, the ambiguity becomes evident. As argued later, the conversion of customary land into leasehold poses a threat, not just to the interests but also the existence of traditional leaders.

\subsection{Land Policy Reforms in Zambia}

The Draft Land Policy published by the Zambian government in 2017 is a more comprehensive update on the two earlier draft documents published in 2002 and 2006 (GRZ 2006). The 2017 draft covers a wide range of land-related issues including international boundaries, different types of land tenure, institutional and legal frameworks, and the valuation and taxation of land. The main aim of the policy reform, according to the state, is to create institutions and a land administration framework which can 'improve on the allocation and management of land uses in the development of the country' (GRZ 2017, 12). Other aims include the promotion of equitable access to land and related resources, strengthening tenure security for all, especially people living on customary land, enhancing sustainable management and productive use of land in a transparent manner. The Draft Land Policy document does acknowledge that the country has had no 'coherent national land policy' since independence, and that this has created several challenges when it comes to managing and administering land. Traditional leaders are not contending these aims and the broader framework; they participated in the deliberation of the national task team and made contributions.

A casual reading of the policy document gives the impression that the proposed reforms are tailored towards protecting the land rights of people on customary land. For example, the document argues that customary land tenure is not secure, and the purpose of this policy is to ensure that these rights are strongly protected. The document indeed strikes a customary-land friendly tone throughout, and one might even wonder why traditional leaders are rejecting a document that seeks to protect and strengthen the rights of people in their communities. The document goes further 
to argue that the current situation perpetuates a tenure dualism that essentially is a continuation of the colonial land system where customary land was treated as an inferior form of landholding.

In order to justify the proposed reforms, the Draft Land Policy document identifies several weaknesses in the current way customary land is administered, including the lack of a land planning system, a situation which according to the draft policy has led to disorderly settlements. The other weaknesses mentioned are the informal nature of land rights under customary tenure, abuse of the powers by traditional leaders, failure to provide equal access to land for women and youth, poor land administration due to lack of a systematic information system for land ownership, and fragmented land administration institutions. The proposed policy reforms seek to recognise customary land just like statutory tenure, by creating what is referred to as 'customary estates', which will make it possible to issue titles 'held in perpetuity and freely transferable through mortgages, leases or sale according to market values and regulation' on customary land (ibid. 22). This, if implemented, would ultimately eliminate the necessity to convert customary land into statutory tenure as is currently the case.

What pushed traditional leaders to contest the proposed land policy reforms is the proposal to change the institutional set-up, particularly the creation of customary land boards, which will take over the administration of customary land. While the Draft Land Policy states that land administration responsibilities will be devolved and administrative tasks will be decentralised to the district and community level, it is the composition of the customary land boards that traditional leaders have found wanting. The main bone of contention is around the fact that, while the traditional leaders will be represented on the district and customary land boards, the allocation of land and the resolution of disputes will be handled by the land boards (ibid. 32). What this proposal entails is that traditional leaders will have effectively lost control over customary land. It is specifically this aspect of the proposed land policy reform that traditional leaders have vehemently rejected, as something that undermines their interest and powers.

\subsection{Traditional Leaders' Response to the Proposed Land Policy Reforms}

In contesting the proposed policy reforms, traditional leaders have argued that the new Draft Land Policy does not take their interest into account. They argue that the proposed changes do not even mention the word 'chiefs', which they interpret as a sign that traditional leaders have been excluded from the administration of customary land (Kapata 2018). In this case, the contest over land resources is not directly about issues of access to land; it is about the rules and structures that govern the day-to-day administration of customary land. Although the state, as a sovereign entity, has the ultimate responsibility over all land in Zambia, the exercise of its 
powers over customary land has been indirectly challenged by traditional leaders. Here, it is important to note that what is being contested is not the territorial authority (sovereignty), but the rules that govern the exercise of power over customary land.

At the Draft Land Policy validation workshop held on 28 March 2018, the 22 representatives of the 288 chiefs in Zambia stormed out of the meeting, stating that they rejected the proposed land policy reforms. The chairperson of the House of Chiefs (which is a statutory body established to deal with matters related to traditional governance)argued that they decided to reject the proposed Draft Land Policy because 'there is no mention of Chiefs in the draft policy document, thereby implying that the institution of Chieftaincy was being abolished' (Kapata 2018, 2). It was also alleged that the concerns raised by traditional leaders in the earlier draft were not considered in the revised draft. Traditional leaders also contested the fact that only 22 out of 288 chiefs were invited to the validation meeting.

To defend their decision to reject the proposed land policy reforms, traditional leaders have argued that customary land belongs to them. They have argued that they defended the land against colonial invasion and will defend the land against anyone who attempts to take it away from them. One of the chiefs interviewed by the press stated that chiefs owned the land even before the state was established and vowed to keep the land for generations to come (Kanyanta 2014).

Traditional leaders have also opposed the policy of converting customary land into leasehold tenure; they have argued that it should be possible to give some form of certificate or title without converting the land to state land. This was articulated in a communique issued by a group of traditional leaders from different part of Zambia who bemoaned the loss of customary land and urged the Zambian government to recognise the documents being issued by traditional leaders on customary land. They noted that:

Once land is converted from customary tenure to leasehold the land does not revert to customary tenure at the expiry or cancellation of the lease. This means that there is a net loss of customary land without corresponding benefits to local communities. There is insecurity on customary tenure as some people are displaced from their land due to large scale land acquisitions without regard to their land rights. ... to ensure tenure security, some chiefs are issuing documents to ascertain user rights and ownership of pieces of land by families. However, such documents are not currently recognized by government. (ZLA 2008)

Interestingly, this is the proposal made in the draft policy to issue titles to people on customary land (GRZ 2017).

Not only that, traditional leaders have also contested the idea of vesting all land in Zambia, including customary land, in the president. They have argued that vesting customary land in the president has rendered traditional leaders' and local people's rights to customary land highly tenuous since the president has powers of eminent domain on customary land (Kanyanat 2014). ${ }^{5}$ Representatives of traditional leaders have recommended that the vestment of land in the president should be removed

\footnotetext{
${ }^{5}$ The principle of eminent domain gives the state the power to expropriate private property, including land, if such a move can be shown to be in the public interest. It has not been widely invoked in Africa; it was widely invoked in the USA in the past.
} 
from the Draft Land Policy and replaced with the classification of land into different categories as envisioned in section 254 of the Constitution (Kapata 2018). Traditional leaders have accused the state of disregarding the cultural rights of Zambians by disrespecting the customary practices around land in rural areas. They have argued that the main problem with land in Zambia is not that traditional leaders are not willing to release land for development, but the state has no capacity to administer land without the help of traditional leaders.

\subsection{The State's Response}

In responding to traditional leaders' walk out of the land policy validation meeting, the Minister of Lands immediately went on national television to assure the public that the new policy has no intention to abolish the institutions of traditional leaders and their responsibility to administer customary land. She argued that the proposed reforms are meant to strengthen the role of traditional leaders in land administration. Not surprisingly, the Minister did not use the 'monopoly of violence' approach or disregard the protesting traditional leaders. Instead, she adopted a conciliatory approach and tone, saying that the Ministry 'shall continue to seek opportunities to engage with the traditional leaders who are key stakeholders to the process. Clarification on the specific issues brought up by the traditional Leaders at the national validation meeting shall be communicated in writing through the office of the Clerk of the House of Chiefs' (Kapata 2018, 5).

\section{Reforming Customary Land Administration}

From the discussion above, it is apparent that the control of customary land is contested. Like in any other contest, the two sides to this contest present different views regarding the proposed land policy reforms. The state, for instance, has presented several arguments to justify its proposal to reform the administration of customary land in Zambia. While the state acknowledges that customary leaders have been instrumental in ensuring access to land in rural communities, it has argued that these land rights are insecure because they are not registered, although they are recognised in law and policy.

The state has also argued that some traditional leaders are abusing their powers over customary land and are alienating large pieces of land to foreign investors at the expense of local communities. The former Minister of Lands in a press statement argued:

while it is true that there are a number of chiefdoms that have been working closely with the Government in looking into the best interests of their subjects, and Government is grateful for that cooperation and support from these chiefdoms, it is equally true that there are certain 
cases in which our people have been exploited by practices that are inconsistent with the law. (Minister of Lands 2013)

The state has acknowledged that, while not all traditional leaders are abusing their powers to administer customary land, there are some who are misusing their powers by selling customary land to foreigners and urban elites. To support his argument, the Minister went on to state:

my office is overwhelmed with cases of Zambians who are complaining of being displaced from their ancestral and family lands in preference for investors and the urban elite at the expense of vulnerable communities including women, youths and differently abled persons. This is against the pro-poor policy of the PF Government which seeks to promote the welfare of all vulnerable groups. (ibid.)

It is interesting here to note that, as a way of validating the legitimacy of the proposed reforms, the state is positioning itself as the protector of poor people in rural areas who are being exploited by the greedy traditional leaders. In doing this, the state is creating justifiable grounds for intervening in the administration of customary land. To support the state's decision to change the institutional arrangement around customary land administration, the Minister appeals not only to the fact that traditional leaders are exploiting the poor, but also to policy and the law. Circular No 1 of 1985, which states that traditional authorities are not allowed to alienate customary land in excess of 250 ha (GRZ 1985, 3), has been referenced (Minister of Lands 2013).

The allegations of flouting the existing laws provide strong grounds for proposing to review and reform the administration of customary land by traditional leaders. The proposed reforms are then expected to close the loopholes in the system so that traditional leaders do not have the chance to abuse their powers. In addition, the state has alleged that traditional authorities are not transparent and accountable in the way they administer customary land. To improve transparency and accountability, the state has proposed to transfer the responsibilities of land administration (including customary land) to statutory bodies at district and community level.

In this contest, we see the state asserting its powers over the governance of customary land by appealing to the law, which is the source of the state's legitimacy. The state is also appealing to its responsibility to promote the general welfare of the people and protect the poor from exploitation. Interestingly, the state has not openly deployed the sovereignty argument to defend its right to formulate and implement land reform. State officials understand that traditional leaders are not contesting the state's sovereign right over its territory. What traditional leaders have focused on is challenging the legitimacy of the state to take away their right to administer customary land. If traditional leaders were to claim autonomy over the land they control, this would be interpreted as challenging the sovereign right of the state. What is happening in the current context is that traditional leaders acknowledge the sovereign right of the state, but contest the proposal to remove the administration of customary land from them. 


\subsection{Traditional Leaders' Power Base}

As may be evident by now, at the heart of this contest is the bid to control customary land. A quick glance at how the contest has played out suggests that traditional leaders are a force to be reckoned with such that the state decided not to deploy the 'monopoly of power' strategy to assert its authority and power. When traditional leaders walked out of the policy validation meeting, the state could have decided to go ahead and validate the policy without the traditional leaders; after all, other stakeholders, including donors, did not walk out. The state could have appealed to the mandate it received from the people of Zambia to govern the country including customary land, but it has not gone that route. This is where the concept of the state as an institution defined by the monopoly of power and violence falls short of providing useful insights into what the state is and its role in society.

As noted in the literature cited above, traditional leaders have demonstrated that they have power to push back the state to defend their interests. One may wonder where did traditional leaders get such powers when they have no army nor guns, they do not control the courts, nor do they have the mandate from the people of Zambia? Could it be that Baldwin (2011) is right in arguing that politicians have ceded the power to control and allocate land to traditional authorities in order to win the rural vote? Or is it that the state in this instance is worried about its capacity to administer land in remote areas (Herbst 2000)? How do we explain what is going on here?

The key to grasping the contest discussed above is to analyse the power base of traditional leaders. I would argue here that the power of traditional leaders in Africa derives from a complex mixture of traditional values and the principles of modern democracy. Their power is not simply derived from the 'ancestralisaton of property' as Boni (2006) asserts, nor simply from the 'deeds of the ancestors' (Berry 2008) or the appeal to ethnic politics (Boone 2017). During the early days of independence, there was a widespread view that the post-colonial African states would wipe away the corrupted forms of traditional governance structures and replace them with centralised monolithic, bureaucratic institutions based on constitutional rule (Baldwin 2011; Nuesiri 2014). But, to the contrary, the importance and power of traditional leaders in Africa are actually being revived (ECA 2007; Nuesiri 2014).

In Zambia, it has been observed that, "Anyone who has intensively and over an extended period of time participated in post-independence Zambian society, cannot help to be aware of the great importance still attached to chiefs'. Nor is this importance limited to rural districts 'outside the line of rail' (Van Binsbergen 1987, 140). Even in countries that have tried to ban or abolish traditional forms of governance, these leaders have continued to survive and command a lot of influence in national politics. We see this in the case presented above, where the state does not take a confrontational approach with chiefs when they protest and reject the Draft Land Policy.

In this regard, the real power of traditional leaders comes from the people's trust in this institution. In a study conducted in Zambia, local residents were asked whether they would prefer the state or the traditional leaders to administer customary land, and majority of the respondents indicated that they would prefer customary land to 
be left in the hands of traditional leaders and this is the reason they gave: "customary land is better because... even people without money are getting customary land, but if the land is under the state it means that everyone will have to buy land, and those without money will not have land' (LURLAP FGD 2014). Baldwin (2011), in a survey of more than 19 African countries, including Zambia, found that majority of the people believe that traditional leaders should have the primary responsibility to administer customary land. Brown et al. (2016) in their study in Botswana and Namibia report similar findings that local people trust their traditional leaders more than elected councillors or MPs. It seems that traditional leaders enjoy a lot of support from local communities when it comes to matters of customary land. This is despite reports that some of the traditional leaders are involved in the alienation of customary land, as mentioned above. In Zambia, there have been several stories, especially in the print media, reporting increasing number of traditional leaders involved in the selling of customary land and pocketing huge sums of money.

But still people trust these leaders, and many rural residents would like them to continue administering customary land. This trust from people has given traditional leaders a great deal of legitimacy even when as reported in the media, they are abusing their authority. In this way, traditional leaders muster a different kind of legitimacy from the state, and they use this to contest land policy and other reforms.

\subsection{The State-traditional Leaders Relationship Over Land in Africa}

The debate on the relationship between the state and traditional leaders in Africa tends to adopt a simplistic approach of attributing the powers of the traditional leaders to colonialism, culture, the weakness of African states, etc. The situation has become a bit more complex with traditional leaders now drawing from both the cultural resources as well as modern governance principles to legitimise their power base. While some analysts have argued that traditional leaders are undemocratic because they are not elected (Ntsebeza 2006), in the wake of the third wave of democratisation in Africa, traditional leaders are increasingly relying on democratic principles and values to bolster their power. Logan (2008), for instance, argues that to understand the seeming incompatibility between traditional leaders and democracy, one must turn to the structure and practice of democratic politics in Africa. If we look at the composition of the electorate in Africa, the majority of voters (on average 65\%) are in rural areas where traditional leaders are not only popular but trusted (Brown et al. 2016). Thus, for politicians seeking to win elections in Africa, they cannot afford to antagonise traditional leaders. While Baldwin (2011) is right in arguing that politicians take into account the implications on the vote when engaging with traditional leaders, the action of politicians is not necessarily a matter of ceding power; there are subtle ways in which the state seeks to regain that power as Lund (2006) has observed. 
On matters relating to land administration and governance, politicians across Africa engage with traditional leaders ambivalently, sometimes forging alliances with them while at other times threatening to discipline them (Herbst 2000; Amanor 2008; Baldwin 2011). This is why the contest over customary land administration in Zambia is not a straightforward case of the state needing to show its force majeure; instead, it seeks to negotiate a new power equilibrium, taking care not to completely alienate traditional leaders. In the Zambian case, the ambiguity in the way the state relates to traditional leaders is evident in both the Movement for Multiparty Democracy (MMD) and Patriotic Front (PF) governments. Under the MMD government, the state enacted the 1995 Lands Act, which seemingly recognised and strengthened the role of traditional leaders in the administration of customary land, while at the same time, the state allowed the conversion of customary land, which has the effect of undermining traditional leaders. Similarly, although many chiefs, under the PF government, have been elevated to the level of senior civil servants with substantial salaries, their role in the administration of customary land in the proposed policy reform is being weakened, as noted above. On the issue of land, both governments have sought to strengthen the power of the state while weakening that of traditional leaders. When traditional leaders realise this, they push back, relying on both democratic and cultural resources.

\section{Conclusion}

This chapter has examined the contestation around the control of customary land in Africa, drawing from the Zambian case study. The chapter has shown that the contending parties present different views around who should be involved in the administration of customary land. The state has argued that the current way customary land is administered lacks transparency, accountability, efficient planning, efficient use, and security of tenure, and that this makes customary land prone to abuse by traditional authorities. The state has used these concerns as justification for embarking on reforming customary land administration and structures, proposing to replace the current structures with statutory bodies, which are envisioned to be more transparent and accountable. Traditional leaders, on the other hand, have rejected the proposed reforms, arguing that the reforms are intended to abolish the institution of traditional leadership.

At the centre of this contestation, is the struggle to gain control of customary land, with both parties well aware that control over land confers power and influence. We see in this case that traditional leaders have power to push back the state when their interests are threatened. While it is puzzling that the state has adopted a conciliatory approach to try and persuade traditional leaders to accept the proposed reforms, it is not surprising that traditional leaders have challenged the proposed land policy reforms. They challenge policy reform drawing from a mixture of cultural power 
and the trust of the people as well as from the dynamic nature of democratic politics. The influence demonstrated by traditional leader in the case of Zambia is not only a result of cultural and ethnic allegiance; it is also a result of politicians being cautious not to antagonise the rural electorate.

Acknowledgements Work for this paper was supported by a grant from the African Studies Centre, Tokyo University of Foreign Studies (TUFS). I would also like to thank participants at the Natural Resource Governance workshop, held in Pretoria in September 2018, for their comments and suggestions. The earlier version of this paper was published as a working paper under the Africa Studies Centre Working Paper Series, Tokyo University of Foreign Studies (TUFS) in 2019.

\section{References}

African Union, African Development Bank, and the Economic Commission for Africa (AU/AfDB/ECA). 2010. Framework and guidelines on land policy in Africa. Addis Ababa: AU/AfDB/ECA.

African Union Commission (AUC). 2017. AU declaration on land issues and challenges: A review of progress made. A report to the conference of the special technical committee on agriculture, rural development, water and environment.

Alden Wily, L. 2003. Governance and land relations: A review of decentralisation of land administration and management in Africa. London: International Institute for Environment and Development (IIED).

Alden Wily, L. 2011. 'The law is to blame': The vulnerable status of common property in subSaharan Africa. Development and Change 42 (3): 733-757.

Amanor, K. 2008. The changing face of customary land tenure. In Contesting land and custom in Ghana: State, chief and the citizen, ed. J. Ubink and K.S. Amanor, 55-112. Leiden: Leiden University Press.

Amanor, K.S., and J. Ubink. 2008. Contesting custom and land in Ghana: Introduction. In Contesting land and custom in Ghana: State, chief and the citizen, ed. J. Ubink and K.S. Amanor, 9-26. Leiden: Leiden University Press.

Baldwin, K. 2011. When politicians cede control of resources: Land chiefs and coalition building in Africa. Afro barometer working paper no 130. University of Cape Town.

Bassett, T. 1993. Introduction: The land question and agricultural transformation in sub-Saharan Africa. In Land in African agrarian systems, ed. T. Bassett and T.J. Crummey, 1-27. Wisconsin: University of Wisconsin Press.

Berry, S. 1993. No condition is permanent: The social dynamics of agrarian change in sub-Saharan Africa. Madison: The University of Wisconsin Press.

Berry, S. 2008. Ancestry property: Land, politics and the deeds of the ancestor in Ghana and Cote d'Ivoire. In Contesting land and custom in Ghana: State, chief and the citizen, ed. J. Ubink and K.S. Amanor, 27-54. Leiden: Leiden University Press.

Berry, S. 2017. Struggles over land and authority in Africa. African Studies Review 60 (3): 105-125.

Blocher, J. 2006. Building on custom: Land tenure policy and economic development in Ghana. Yale Human Rights and Development Law Journal 9: 166-202.

Boni, S. 2006. Indigenous blood and foreign Labor: The ancestralization of land rights in Sefwi (Ghana). In Land and the politics of belonging in West Africa, eds. R. Kuba, and C. Lentz, 161-186. Leiden, Boston: Brill.

Boni, S. 2008. Traditional ambiguities and authoritarian interpretations in Sefwi land disputes. In Contesting land and custom in Ghana: State, chief and the citizen, ed. J. Ubink and K.S. Amanor, 81-112. Leiden: Leiden University Press. 
Boone, C. 2017. Sons of the soil conflict in Africa: Institutional determinants of ethnic conflict over land. World Development 96 (3): 276-293.

Brown, L., T. Falk, D. Kgathi, M. Kirk, and C. Mapaure. 2016. The acceptance of traditional authorities in the Okavango basin: An experimental study in Namibia and Botswana. (A Paper presented at the World Bank Conference on Land and Poverty, 14-18 March 2016, Washington, DC.)

Bruce, J. 1982. Land tenure issues in project design and strategies for agriculture development in sub-Saharan Africa. Land tenure centre paper No 128. University of Wisconsin.

Bruce, J. 2014. Decentralisation of land administration in sub-Saharan Africa: Recent experiences and lessons learned. In Agricultural land redistribution and land administration in sub-Saharan Africa: Case studies of recent reforms, ed. F.K. Byamugisha, 55-84. Washington, DC: World Bank.

Chimhowu, A. 2019. The 'new' African customary land tenure: Characteristic, features and policy implications of a new paradigm. Land Use Policy 81: 897-903.

Chitonge, H. 2015. Customary land at a crossroads: Contest for the control of customary land in Zambia. SADC Law Journal 4 (1): 45-67.

Deininger, K., and H. Binswanger. 1999. The evolution of the World Bank's land policy: Principles, experiences and future challenges. The World Bank Research Observer 14 (2): 247-276.

Deininger, K., and G. Feder. 2009. Land registration, governance and development: Evidence and implications for policy. The World Bank Research Observer 24 (2): 233-262.

Deutsche Gesellschaft fur Internationale Zusammenarbeit (GIZ). 2018. The role and recognition of land governance in GIZ projects in Africa, counterpart strategies and investment plans. Frankfurt: GIZ.

Feder, G., and A. Nishio. 1999. The benefits of land registration and titling: Economic and social perspectives. Land Use Policy 15 (1): 25-43.

Government Republic of Zambia (GRZ). 1985. Administrative circular No 1 of 1985. Lusaka: Ministry of Lands.

Government Republic of Zambia (GRZ). 2006. Draft land policy. Lusaka: Ministry of Lands.

Government Republic of Zambia (GRZ). 2017. Draft national land policy. Lusaka: Ministry of Lands.

Herbst, J. 2000. States and power in Africa: Comparative lessons in authority and control. Princeton: Princeton University Press.

Honig, L., and B. Mulenga. 2015. The status of customary land and the future of smallholder farmers under the current land administration system in Zambia. IAPRI Working Paper No. 101. Lusaka.

International Monetary Fund. 1997. Good governance: The IMF's role. Washington, D.C.: IMF.

Jackson, R. 1990. Quasi-states: Sovereignty, international relations and the third world. Cambridge: Cambridge University Press.

Jackson, R., and C. Rosberg. 1982. Why Africa's weak states persist: The empirical and juridical in statehood. World Politics 35 (1): 1-24.

Kabilika, E. 2010. The status of customary land and how it affects the rights of indigenous local communities. Zambia: Caritus.

Kanyanta, C. 2014. The institution of chiefs is on slippery ground-Chitimukulu. Lusaka Times.

Kapata, J. 2018. Press statement by Honourable Jean Kapata, MP, Minister of Lands and Natural Resources on the outcome of the National Land Policy validation meeting held on Monday, 28 February 2018. Available at https://www.lusakatimes.com/2018/03/03/reaction-traditionalleaders-land-policy-meeting-extremely-surprising-jean-kapata/

Logan, C. 2008. Traditional leaders in modern Africa: Can democracy and chiefs co-exist? Afrobarometer Working Paper No 93. University of Cape Town.

Lund, C. 1998. Struggles for land and political power: On the politicisation of land tenure and disputes in Niger. Journal of Legal Pluralism 40: 1-22.

Lund, C. 2006. Twilight institutions: Public authority and local politics in Africa. Development and Change 37 (4): 685-705. 
Lund, C., and C. Boone. 2015. Land politics in Africa: Constituting authority over territory, property, and persons. Africa 83 (1): 1-13.

Mafeje, A. 2003. The Agrarian question, access to land, and peasant responses in sub-Saharan Africa. United Nations Research Institute for Social Development, Programme Paper No. 6. Geneva: UNRISD.

Mamdani, M. 1996. Citizens and subjects: Contemporary Africa and the legacy of late colonialism. Princeton: Princeton University Press.

Minister of Lands. 2013. Policy statement by Hon. Harry Kalaba, MP, Minister of Lands, Natural Resources and Environment. On the protection and administration of customary land in Zambia. Issued on 13 December 2013. Available at www.parliament.gov.zm/sites/default/files/images/ publication_docs/Minsterial\%20Statement\%20-\%20MOL.pdf

Moyo, S. (2008). African Land Questions, Agrarian Transition and the State: Contradictions of the Neo-liberal Land Reforms. Dakar: CODESRIA

Mulolwa, A. 2016. Land governance assessment: Zambia country report. Lusaka: World Bank.

Ntsebeza, L. 2006. Democracy compromised: Chiefs and the politics of land in South Africa. Leiden/Boston: Brill.

Nuesiri, E. 2014. Re-emergence of customary authorities and its relation with local democratic government. Dakar: CODESRIA.

Okoth-Ogendo, H. 1989. Some theory in the study of tenure relations in African agriculture. Journal of International African Institute 59 (1): 6-17.

Peters, P. 2004. Inequality and social conflict over land in Africa. Journal of Agrarian Change 4 (3): 269-314.

Platteau, J.-P. 2000. Does Africa need land reform? In Evolving land rights, policy and tenure in Africa, ed. C. Toumin and J. Quan, 51-73. London: IIED/DFID.

Shipton, P., and M. Goheen. 1992. Understanding African land-holding: Power and meaning. Journal of International African Institute 62 (3): 307-325.

Stark, F. 1986. Theories of contemporary state formation in Africa: A reassessment. Journal of Modern African Studies 24 (2): 335-347.

Sitko, N., J. Chamberlin, and M. Hichaambwa. 2015. The geography of customary land in Zambia: Is development strategy engaging with facts? IAPRI working paper No 98. Lusaka.

Tilly, C. 1985. War making and state making as organised crime. In Bringing the State Back In, ed. P. Evans, D. Rueschemeyer, and T. Skocpol, 169-187. Cambridge: Cambridge University Press.

United Nations Economic Commission for Africa (ECA). 2007. Relevance of African traditional institution of governance. Addis Ababa: ECA.

Van Binsbergen, W. 1987. Chiefs and the state in independent Zambia: Exploring the Zambian national press. Journal of Legal Pluralism 25 (26): 139-172.

Werner, W. 2018. Land tenure and governance on communal land in Namibia. In A paper presented at the second national land conference, Windhoek, 1-5 October 2018.

World Bank. 1992. Governance and development. Washington, DC: World Bank.

World Bank. 2005. Meeting the challenge of Africa's development: A World Bank Group action plan. New York: IBRD/World Bank.

Zambia Land Alliance (ZLA). 2008. Land policy options for development and poverty reduction: Civil society views for pro-poor land policies and laws in Zambia. Lusaka: Civil Society Consultative Forum. 
Open Access This chapter is licensed under the terms of the Creative Commons Attribution 4.0 International License (http://creativecommons.org/licenses/by/4.0/), which permits use, sharing, adaptation, distribution and reproduction in any medium or format, as long as you give appropriate credit to the original author(s) and the source, provide a link to the Creative Commons license and indicate if changes were made.

The images or other third party material in this chapter are included in the chapter's Creative Commons license, unless indicated otherwise in a credit line to the material. If material is not included in the chapter's Creative Commons license and your intended use is not permitted by statutory regulation or exceeds the permitted use, you will need to obtain permission directly from the copyright holder.

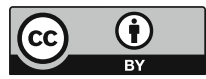

